\title{
The clinical consequences of sucrase-isomaltase deficiency
}

\author{
Stanley A. Cohen
}

\begin{abstract}
Primary sucrase-isomaltase deficiency, originally thought to be a homozygous recessive disorder, has been found to have numerous genetic variants that alone or in combination (compound heterozygosity) express varying degrees of clinical illness, most commonly causing chronic diarrhea, abdominal pain, and bloating. These symptoms are also present with secondary sucrase-isomaltase deficiency. Recent investigations are providing evidence that sucrase-isomaltase deficiency is more prevalent and of greater clinical significance than previously suspected. Further research is required to correlate the specific genotypes and phenotypes with their clinical expressions and to determine the most appropriate treatment algorithm for these patients.
\end{abstract}

Keywords: Sucrase, Sucrase-isomaltase deficiency, Sacrosidase, Genetic sucrase-isomaltase deficiency, Heterozygous carriers

\section{Introduction}

The linked disaccharidase, sucrase-isomaltase, is a glycoprotein localized to the brush border membrane of small intestinal villi. Sucrase-isomaltase is synthesized and assembled in the rough endoplasmic reticulum as a homologous pro-enzyme dimer which passes through the Golgi apparatus and is transported to the apical cell surface of villi [1]. There, it is cleaved into its mature subunits, sucrase and isomaltase, by pancreatic proteases. Isomaltase cleaves branched (1-6 linked) $\alpha$-limit dextrins, while sucrase digests sucrose, maltose, short 1-4 linked glucose oligomers, and some branched starches into sugar monomers for intestinal absorption, its activity often overlapping with maltase-glucoamylase [2]. The cleaved monosaccharides are then transported across the epithelial brush border for absorption and metabolism. Sucrase is an inducible enzyme in early development, such that increased exposure to sucrose, or the stress of doing so, increases sucrase activity [3-7].

\section{Review}

\section{Deficiency states}

The first report of an autosomal recessive disaccharidase deficiency was congenital sucrase-isomaltase deficiency

\footnotetext{
Correspondence: stancohen@aol.com

Children's Center for Digestive Health Care, Children's Healthcare of Atlanta, 993D Johnson Ferry Road NE, Suite 440, Atlanta, GA 30342, USA
}

(CSID) in 1960 [8]. The affected children presented with osmotic diarrhea, mild steatorrhea, chronic diarrhea, irritability, and vomiting after consuming sucrose [9]. The difficulty in providing adequate nutrition to these patients can lead to dehydration, metabolic acidosis, hypercalcemia, failure to thrive, and developmental delay. CSID was originally believed to be rare, occurring primarily among the native population of Alaska and Greenland [10, 11]. A trafficking defect with intracellular accumulation of prosucrase-isomaltase in the Golgi apparatus was found to be responsible [1].

\section{Genetic factors}

Since the discovery of the initial trafficking error, other phenotypes have been discovered [12] and, currently, seven phenotypes are known [13]. More than 25 mutations within the human sucrase gene are responsible for these CSID phenotypes [14]. Some sucrase-isomaltase variants show classical autosomal recessive homozygous inheritance, while others demonstrate compound heterozygote inheritance [15]. Sucrase-isomaltase variants can occur on either sucrase or isomaltase subunits, resulting in varied effects on sucrase-isomaltase enzyme activity [16].

There is now strong evidence that heterozygous carriers also experience symptoms of CSID, such as chronic diarrhea, abdominal pain, and bloating [17]. It is currently estimated that 2-9 \% of Americans of European descent may be affected, suggesting that sucrase-isomaltase deficiency

\section{Springer}

(c) 2016 Cohen. Open Access This article is distributed under the terms of the Creative Commons Attribution 4.0 International License (http://creativecommons.org/licenses/by/4.0/), which permits unrestricted use, distribution, and reproduction in any medium, provided you give appropriate credit to the original author(s) and the source, provide a link to the Creative Commons license, and indicate if changes were made. 
has been greatly underrecognized [17]. Therefore, the newer term genetic sucrase-isomaltase deficiency (GSID) should be used to encompass the entire range of inheritance patterns while CSID is reserved to specifically identify homozygous recessive individuals.

For example, the sucrase-isomaltase variants V577G and G1073D result in blocked transport in the ER loss of normal enzyme activity while the sucrase-isomaltase variant V15F has reduced cell surface expression resulting in decreased sucrase activity [16]. Analyses at the cellular, molecular, and functional levels of 11 novel cases with CSID revealed three categories of sucrase-isomaltase variants: transport competent, partially transport competent, and transport incompetent [18]. Patients with all three variant categories showed reduced or drastically reduced enzymatic activities of sucrase and isomaltase and symptoms resembling irritable bowel syndrome [17].

\section{Secondary or acquired sucrase-isomaltase deficiency}

Available evidence suggests that other forms of chronic diarrhea share some of the features of GSID and may represent acquired or secondary forms of sucraseisomaltase deficiency. For example, a reduced height of intestinal villi in pigs is directly correlated with reduced brush-border enzyme activity, specifically lactase, sucrase, and maltase [19]. Clinically, the reduced enzymatic activity and villous atrophy in the small intestine are associated with maldigestive and malabsorptive diarrhea [20]. Numerous human gastrointestinal disorders, such as celiac disease, are also associated with villous atrophy and diarrhea and may represent secondary or acquired forms of sucrase-isomaltase deficiency (Table 1) [21]. In these disorders, the clinical impact of sucrase-isomaltase deficiency is often transient, with enzymatic activity gradually returning to normal or near normal as the underlying disorder is successfully resolved.

\section{Clinical features}

Whether due to a primary (genetic) or secondary (acquired) deficiency, absent or diminished enzyme activity allows undigested sugars to accumulate in the lumen of the small intestine, resulting in the clinical effects of sucrase-isomaltase deficiency [12]. The osmotic effect of malabsorbed sugars contributes to watery, hyperosmolar diarrhea. Subsequently, other symptoms are caused by the fermentation of undigested sucrose by colonic bacterial microflora which release methane, hydrogen, and carbon dioxide causing bloating and abdominal pain [22].

Symptom severity becomes a function of residual sucrase and isomaltase activity, amount of sugar and starch consumed, extent of buffering by other foods, and gastric emptying [22]. Frequent diarrhea can be the result and
Table 1 Potential causes of secondary or acquired sucraseisomaltase deficiency or maldigestion

Villous atrophy or alteration
Celiac disease
Non-tropical sprue
Chemotherapy and radiation enteropathy
Crohn's disease
Allergic enteropathy
Immunodeficiency
Malnutrition
Infection
Acute gastroenteritis
Giardiasis
Tropical sprue
HIV enteropathy
Small intestinal bacterial overgrowth
Rapid transit
Rapid gastric emptying
Chronic nonspecific diarrhea
Dumping syndrome
Ulcerative, microscopic, and lymphocytic colitis

also the cause of rapid small-bowel transit. The degree of fermentation of any malabsorbed carbohydrates by the colonic bacteria can also stimulate diarrhea and further lessen exposure time for existing enzymes to digest substrate [22]. Children are more susceptible to the symptoms of sucrase-isomaltase deficiency because the length of their small intestine is shorter and the reserve capacity of the colon to absorb excess luminal fluid is reduced [22]. Consequently, symptoms sometimes improve with age.

The current standard for the diagnosis of sucraseisomaltase deficiency is to assay duodenal or jejunal mucosa biopsy specimens for lactase, sucrase, isomaltase (palatinase), and maltase activity [22, 23]. In addition to the usual histological specimens obtained at the time of upper endoscopy, several biopsies are sampled from the distal duodenum or jejunum, immediately frozen and sent to a laboratory, and assayed for enzyme activity. The standard assay is the Dahlquist method which incubates the biopsied tissue together with the appropriate substrate and measures the released glucose. Using this method, disaccharidase activity in the duodenum can be almost $40 \%$ less than that in the proximal jejunum [24]. Additionally, the broad effectiveness of SI in digesting 1,4-linkages results in a tight correlation of sucrase activity with maltase and isomaltase activity [25].

The invasiveness of obtaining biopsies for disaccharidase assays has led to the development of surrogate methods, based on the exhalation of gases produced by the enzymatic degradation of the substrate which reflect the clinical 
effect of sucrose intolerance. The sucrose hydrogen breath test is easily performed by having the patient drink a standard amount of sucrose or ${ }^{13} \mathrm{C}$-sucrose. The amount of expired hydrogen or ${ }^{13} \mathrm{C}$-methane measured in expired breath correlates well with intestinal enzyme activity [26]. More recently, sucrase-isomaltase exome genetic sequencing has become available for identifying homozygous and compound heterozygote mutations responsible for genetic sucrase-isomaltase deficiency [16]. Additionally, dietary modification and oral enzyme replacement trials using synthetic sucrase (sacrosidase) have been employed to determine if they can clinically alleviate symptoms of sucrase-isomaltase deficiency $[22,23]$.

\section{Growing prevalence of sucrase-isomaltase deficiency}

A retrospective study assessed levels of disaccharidase activity in mucosal biopsy tissue samples referred to a large gastrointestinal specialty laboratory over a 6-year period $(N=27,875)$ [27]. These specimens, most of which were collected during pediatric endoscopies, revealed at least one disaccharidase deficiency in $45 \%$ of samples. Among these, $21 \%$ were sucrase deficient, indicating that $9.3 \%$ of the specimens showed low sucrase activity.

Subsequently, a prospective pilot study assessed the prevalence of disaccharidase abnormalities in children with recurrent abdominal pain undergoing upper endoscopy (esophagogastroduodenoscopy (EGD)) $(N=28)$. Among them, 15 (53.6 \%) had low lactase levels, 4 $(14.3 \%)$ had low sucrase levels, 5 (17.9\%) had low maltase, and 4 (14.3\%) had low glucoamylase activity. Clinical characteristics did not correlate with the degree of disaccharidase deficiency [28]. More recently, a retrospective review studied 963 symptomatic children undergoing upper endoscopy and disaccharidase testing. Among those, 73 (7.6\%) were sucrase deficient, defined as enzyme activity $<25 \mu \mathrm{mol} / \mathrm{min} / \mathrm{g}$. Only 4 children (5\%) had isolated sucrase-isomaltase deficiency, with the others also having lactase deficiency or pan-disaccharidase deficiency when all enzymes were measured $(n=44 ; 60 \%)$. Abnormal biopsies were found in 33 children (45\%). Most had abdominal pain $(n=49 ; 78 \%)$ and/or diarrhea $(n=27$; $43 \%)$. The final diagnosis for these 73 patients is shown in Fig. 1. It is important to note, however, that even though disaccharidase deficiencies were found on biopsy, the attending physician may not have accepted the deficiency as the primary diagnosis [25].

Thus, there is still concern that the cited studies underestimate the prevalence and only comprise a limited view of SID. In a study of 65 children diagnosed with GSID, 53 reported the onset of symptoms before 1 year of age; however, only 17 were diagnosed by that time and 30 were not diagnosed until 5 years of age [19]. While some are correctly diagnosed, many others may be missed due to dietary elimination of high sucrose or high starch foods as food allergies or misdiagnosed as chronic nonspecific diarrhea or diarrhea-predominant irritable bowel syndrome. As a result, it is incumbent upon us to more fully understand the clinical consequences of SID. Population-based and well-controlled studies are needed to explore the relationship of the various genetic and secondary deficiencies and correlate them with their clinical manifestations and response to therapy.

\section{Conclusions}

Sucrase-isomaltase deficiency is more prevalent than previously suspected and often contributes to significant symptoms for patients with either primary or secondary

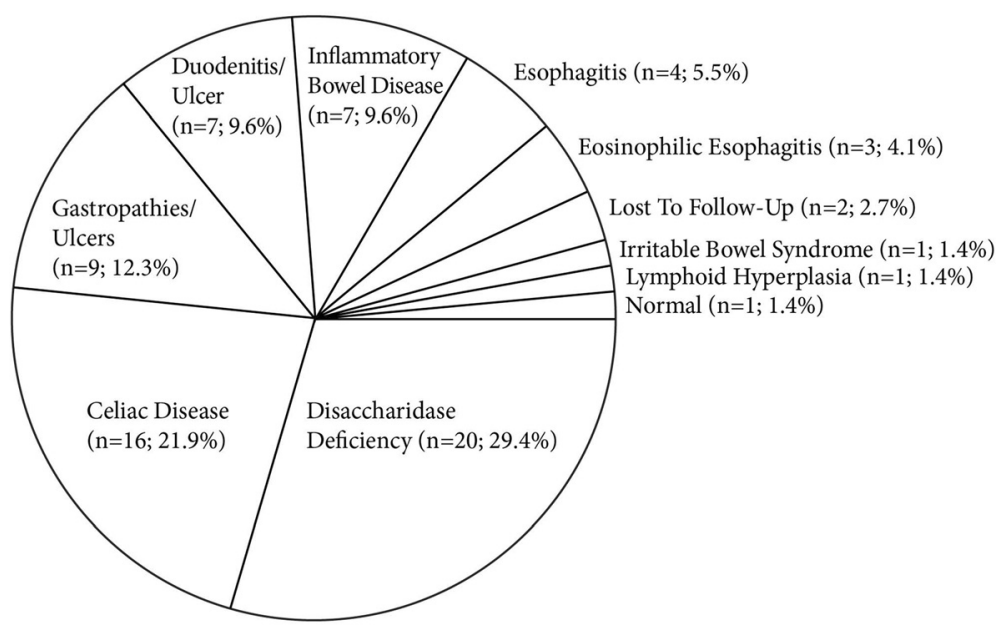

Fig. 1 Primary diagnosis of symptomatic children undergoing upper endoscopy and disaccharidase testing. Final diagnosis on the visit after EGD and disaccharidase testing among 73 children who were sucrase deficient (enzyme activity $<25 \mu \mathrm{mol} / \mathrm{min} / \mathrm{g}$ ) 
disease. Further research is required to correlate the genotype with a phenotype and to determine the appropriate treatment algorithm for these patients.

\section{Competing interests}

The author further notes that he serves as a constultant for QOL Medical and that theyprovide research support

\section{Acknowledgements}

The author acknowledges the editorial assistance of Dr. Carl S. Hornfeldt, Apothekon, Inc., with funding provided by the QOL Medical, LLC, Vero Beach, FL, USA.

Received: 29 July 2015 Accepted: 22 December 2015

\section{2.}

\section{References}

1. Hauri HP, Roth J, Sterchi EE, Lentze MJ (1985) Transport to cell surface of intestinal sucrase-isomaltase is blocked in the Golgi apparatus in a patient with congenital sucrase-isomaltase deficiency. Proc Natl Acad Sci U S A 82(13):4423-4427

2. Treem WR (1995) Congenital sucrase-isomaltase deficiency. J Pediatr Gastroenterol Nutr 21:1-14

3. Prestidge LS, Spizizen J (1969) Inducible sucrase activity in Bacillus subtilis distinct from Levan-sucrase. J Gen Microbiol 59:285-288

4. Goldstein R, Klein T, Freier S, Menczel J (1971) Alkaline phosphatase and disaccharidase activities in the rat intestine from birth to weaning. I. Effect of diet on enzyme development. Am J Clin Nutr 24:1224-1231

5. Celano P, Jumawan J, Horowitz C, Lau H, Koldovsky O (1977) Prenatal induction of sucrase activity in rat jejunum. Biochem J 162:469-472

6. Goda TBS, Edmond J, Grimes J, Koldovský O (1985) Precocious increase of sucrase activity by carbohydrates in the small intestine of suckling rats. II. Role of digestibility of sugars, osmolality, and stomach evacuation in producing diarrhea. J Pediatr Gastroenterol Nutr 4:634-638

7. Greene HL, Stifel FB, Herman RH (1972) Dietary stimulation of sucrase in a patient with sucrase-isomaltase deficiency. Biochem Med 6:409-418

8. Weijers HA, van de Kamer JH, Mossel DA, Dicke WK (1960) Diarrhoea caused by deficiency of sugar-splitting enzymes. Lancet 2:296-297

9. Gudmand-Hoyer E, Krasilnikoff PA (1977) The effect of sucrose malabsorption on the growth pattern in children. Scand J Gastroenterol 12:103-107

10. Bell RR, Draper HH, Bergan JG (1973) Sucrose, lactose, and glucose tolerance in northern Alaskan Eskimos. Am J Clin Nutr 26(11):1185-1190

11. Gudmand-Hoyer E, Fenger HJ, Kern-Hansen P, Madsen PR (1987) Sucrase deficiency in Greenland. Scand J Gastroenterol 22:24-28

12. Naim HY, Roth J, Sterchi EE, Lentze M, Milla P, Schmitz J, Hauri HP (1988) Sucrase-isomaltase deficiency in humans. Different mutations disrupt intracellular transport, processing, and function of an intestinal brush border enzyme. J Clin Invest 82:667-679

13. Naim HY, Amiri M, Gericke B (2012) Structural, cellular and functional features of novel mutants of sucrase-isomaltase in congenital sucraseisomaltase deficiency

14. Sander P, Alfalah M, Keiser M, Korponay-Szabo I, Kovacs JB, Leeb T, Naim HY (2006) Novel mutations in the human sucrase-isomaltase gene (SI) that cause congenital carbohydrate malabsorption. Hum Mutat 27(1):119. doi:10.1002/humu.9392

15. Chumpitazi BP, Robayo-Torres CC, Opekun AR, Nichols BL Jr, Naim HY (2012) Congenital sucrase-isomaltase deficiency: summary of an evaluation in one family. J Pediatr Gastroenterol Nutr 55(Suppl 2):S36

16. Alfalah M, Keiser M, Leeb T, Zimmer KP, Naim HY (2009) Compound heterozygous mutations affect protein folding and function in patients with congenital sucrase-isomaltase deficiency. Gastroenterology 136:883-892

17. DeJonge AM, Norris KS, Hernandez K, Elser H, Opekun AR (2014) Sucraseisomaltase genetic variant carriers can be symptomatic. Gastroenterology 146:S705

18. Gericke B, Amiri M, Naim HY (2013) Structural, cellular and functional features of novel mutants of sucrase-isomaltase in congenital sucraseisomaltase deficiency. JPGN 57(Suppl 1):E117

19. Tsukahara T, Kishino E, Inoue R, Nakanishi N, Nakayama K, Ito T, Ushida K (2013) Correlation between villous height and the disaccharidase activity in the small intestine of piglets from nursing to growing. Anim Sci J 84:54-59
20. Jung K, Ahn K, Chae C (2006) Decreased activity of brush border membrane-bound digestive enzymes in small intestines from pigs experimentally infected with porcine epidemic diarrhea virus. Res Vet Sci 81:310-315

21. Lebwohl B, Murray JA, Rubio-Tapia A, Green PH, Ludvigsson JF (2014) Predictors of persistent villous atrophy in coeliac disease: a populationbased study. Aliment Pharmacol Ther 39:488-495

22. Treem WR (2012) Clinical aspects and treatment of congenital sucraseisomaltase deficiency. J Pediatr Gastroenterol Nutr 55:S7-13

23. Puntis JW, Zamvar V (2015) Congenital sucrase-isomaltase deficiency: diagnostic challenges and response to enzyme replacement therapy. Arch Dis Child. [Epub ahead of print]

24. Rana SV, Bhasin DK, Katyal R, Singh K (2001) Comparison of duodenal and jejunal disaccharidase levels in patients with non ulcer dyspepsia. Trop Gastroenterol 22:135-136

25. Cohen SA (2015) Disaccharidase activity in children undergoing esophagogastroduodenoscopy. Presented: North American Society for Pediatric Gastroenterology, Hepatology and Nutrition, Washington, A536, Oct 10, 2015

26. Robayo-Torres CC, Opekun AR, Quezada-Calvillo R, Villa X, Smith EO, Navarrete M, Baker SS, Nichols BL (2009) 13C-breath tests for sucrose digestion in congenital sucrase isomaltase-deficient and sacrosidasesupplemented patients. J Pediatr Gastroenterol Nutr 48:412-418

27. Nichols BL Jr, Adams B, Roach CM, Ma CX, Baker SS (2012) Frequency of sucrase deficiency in mucosal biopsies. J Pediatr Gastroenterol Nutr 55(Suppl 2):S28-30

28. Chumpitazi BP, Robayo-Torres CC, Tsai CM, Opekun AR, Baker SS, Nichols BL, Gilger MA (2013) Yield of prospective disaccharidase testing in children with recurrent abdominal pain. Gastroenterology 144(5 Suppl 1):S401-402

\section{Submit your manuscript to a SpringerOpen ${ }^{\circ}$ journal and benefit from:}

- Convenient online submission

- Rigorous peer review

- Immediate publication on acceptance

- Open access: articles freely available online

High visibility within the field

- Retaining the copyright to your article

Submit your next manuscript at $\gg$ springeropen.com 